The process may be described in a very few lines. In the first place a negative is taken on a gelatine plate, which has been specially prepared. The plate is developed and fixed in the ordinary way, and the image appears of the same character as if taken on a good density-giving plate. A transparency (a positive) is next taken on a similar plate from this negative, or a silver print made on specially prepared albumenised paper, on either of which the colour process is worked. The colouring is of a very simple nature. There are three dyes-a crimson-red, a grass-green, and a very good blue, all in solution, and mixed with some other ingredients besides water. There is also what we may call a mordant in the shape of a colourless liquid containing, I should say, albumen and salt.

This last liquid is brushed copiously over the face of the positive (or the silver print), and the blue dye applied a little at a time. If the light be good (and it was stated that the colouring must take place in good daylight), the blue dye rapidly takes hold of those portions of the surface which represent in monochrome what are blues in the original. For instance, a china vase will take the blue tint, and the face or hands a faint amount of the same colour. The green dye is applied in the same manner, and the greens in the original make their appearance in the positive, and so with the red. Finally the print or positive presents a picture in colours, underlying which is the dark brown silver image. It appears as if the image took up selectively these three colours; but why it takes them up, it is hard to see. I have by me a portrait done in the manner described, and the negative has evidently been retouched with the pencil. It is difficult to understand why a pencil mark should be the cause of selective absorption of the colours, or that a special plate should be necessary. That the success of the process does not depend upon the inventor's manipulation is quite evident, for negatives were taken by Sir H. T. Wood, quite independently of him, but of course on prepared plates given him for the purpose, and from these he made positives. These last, when treated with the colouring matter, gave the correct colours of the original. Still I am somewhat sceptical-I believe it is my failing to be so-and I shall not be satisfied till I get the plates that have been promised me by the inventor (M. Chassagne), and taken negatives of certain test objects which will be unknown to the inventor. If he can reproduce their colours it will have to be without any reference to the amounts of silver which ordinarily indicate the colour in the original, for in the negatives sent every colour will be represented by approximately an equal density. Some few years ago a powder process was seen by Mr. C. V. Boys, in which three coloured powders selectively adhered to the surface of paper. The paper was prepared with some glutinous substance and bichromate of potash, and which remained more or less tucky according to the amount of exposure to light it received. These three powders, a red, a green, and a blue, I believe, if applied in a certain order, adhered to the print, and gave approximately correct results of colour, though no special negative was required. Whether this new process now described depends on any similar grounds, it is hard to say at present.

The point that strikes me in the latest process is that it is only from a specially prepared negative that a print suitable for colouring can be made. Were it the negative which took up the colour, one might understand the matter better. To me at present the process as stated is a mystery; but if it does all that it is claimed for it, it must be a great success, and the theory of it will have to be investigated in a thoroughly scientific manner. At present the details are a secret; but I am given to understand that the seal of secrecy will be withdrawn before long, as a patent is applied for. We shall then be able to ascertain on what principles the process is worked.

NO. I 423 , vOL. 55$]$

\section{BRITISH ASSOCIATION MEETING IN TORONTO.}

\section{I.--LOCAL ARRANGEMENTS.}

THE various special Local Committees, organised to make preparations for the British Association meeting, to take place in Toronto this year, have now, after a year's work, to report very satisfactory progress in the arrangements for the occasion. In the case of some of the Committees, their work may be considered as finished. The special Committee on Finance, for instance, has secured promises of financial aid to the extent of $5700 \%$. from the Governments of the Dominion of Canada and the Province of Ontario, and from the Toronto City Council. This sum will, it is believed, be fully sufficient for all the expenses of the meeting, which, owing to the special circumstances of the occasion, must be larger than those of any meeting in Great Britain.

The Committee on Rooms also has, for the present, finished its labours. According to its report, which has been adopted by the Local Executive Conmittee, the reception room, general offices, and the rooms for the sectional meetings are all to be in the various lecture rooms and laboratories of the University of Toronto and of the School of Practical Science. As the buildings of the University and School are in the centre of the city, and within less than five minutes' walk from the electric car line which communicates with all parts of the city, the selection offers every convenience in the way of conveyance. The rooms selected are large and well adapted for the purposes assigned, and all are within a short distance of each other. Sections $\mathrm{A}$ and $\mathrm{H}$ (Mathematical and Physical Science and Anthropology) will occupy lecture-rooms in the main building of the University, Sections D, I and K (Zoology, Physiology and Botany) are allotted rooms in the Biological building, Section $\mathrm{B}$ (Chemistry) will be placed in the Chemical building, Section E (Geography) in the general reading-room of the University library, while Sections $C, F$ and $G$ (Geology, Economics and Mechanical Science) are to be given large rooms in the University Y.M.C.A. building, Students' Union building, and in the School of Practical Science respectively. The only building to be used by the Association, and not situated on the University grounds, is Massey Hall, in which will be delivered the President's address and the evening lectures. It is capable of seating 4000 persons, and has splendid acoustic properties.

One of the conversaziones will be held in the main building of the University ; the other will, it is expected, be given in the new buildings of the Provincial Legislature. A number of gentlemen have kindly offered to give garden parties, while the Faculties of Trinity College and Victoria College have arranged to hold receptions. The various Clubs in the city will be open to the members of the Association.

The arrangements for conveyance are not yet completed, but the concessions already made by the Steamship and Railway Companies may be announced. The Canadian Steamship Companies, the Allan, Dominion and Beaver Lines (Liverpool and Londonderry to Quebec and Montreal) have granted to members of the Association considerable reductions in rates for single and return tickets, and the Anchor Line (Glasgow and New York) offer reasonable rates for single or return firstclass tickets. A copy of a circular giving information in regard to Atlantic steamship rates will be sent to each member of the Association in a few weeks. It may be well to note that berths are to be applied for early in the season; for the choice, if made late in June or July, may not be a laroe one. The Canadian Pacific and Grand Trunk Railway Companies have decided that round 
(return) trip first-class tickets over their lines may be obtained by members for the single fare, and that for single trips between points on their lines in Canada east of Port Arthur (on Lake Superior) only half rates ( $\frac{3}{4} d$. per mile) will be charged. The Canadian Pacific Railway Company will also give free tickets for trips over the branch roads of the main line in the North-west and British Columbia, and will arrange a special excursion to the Pacific Coast, to take place after the meeting, for a number of members and guests of the British Association.

Additional excursions to other parts of Canada have been provided for. Niagara Falls may be reached from Toronto in three hours by the large fine steamers of the Ontario Navigation Company, which ascend the Niagara River to a point connected with the Falls by two electric car lines. This excursion may be made on any day, and an opportunity will be offered to visitors to spend the time from Saturday to Monday at the Falls. It is expected also that members will have the privilege of inspecting the means employed of "harnessing Niagara." Another excursion, to the beautiful Muskoka Lake region, Ontario's summer resort, four hours (by rail) distant from Toronto, is offered. The members may leave Toronto at $3 \mathrm{p.m}$. on Saturday, August 2 r, and return early Monday morning. There will be, on an afternoon during the meeting, an excursion to the Ontario Agricultural College and Farm, in the neighbourhood of the town of Guelph. The Committee on Excursions is providing also for a number of special excursions to Nova Scotia, Kingston, and the 'Thousand Islands, Montreal, Ottawa, the Upper Lakes, to cover from five days to three weeks. The town authorities of Sudbury are preparing for an excursion of members to that district, in which are to be found the richest nickel mines in the world. Parties interested in mining also will, by special excursions, visit the Western Ontario gold mines, and the gold mines of British Columbia, which at present are attracting much attention.

The special Committee on Publication is preparing a hand-book of the Dominion, which will give an account of its resources, and of its geological, climatic and other features. It is expected that copies of this hand-book will be ready for distribution amongst the members before they start for Canada.

The Local Committee has decided to invite a number of distinguished continental (European) scientific men, and it is believed that not a few of these will accept the invitation. A very large number, also, of prominent American scientific men have expressed their intention of attending the meeting. The American Association for the Advancement of Science meets on August 9, at Detroit, 240 miles from Toronto, in order to allow its members to be present at the meeting of the British Association. The Society of American Naturalists, the American Psychological Association-both very important and strong organisations-have accepted for their members invitations to join the British Association and attend its meetings. It is confidently believed that the Toronto meeting will have very largely an international character, and that the numbers in attendance will be very great.

The people of the Dominion in general, and of Toronto especially, are determined that the coming meeting shall not fall one whit in interest behind any meeting held in the British Isles. As the time approaches, the interest in it daily increases. Canadians realise also that it is a rare opportunity to show what their country is in grandeur, in extent, and in resources; and they will leave nothing undone which will make the meeting a success from every point of view. It must also be said that for the British man of science the occasion is the opportunity of a life-time.

NO. I 423 , VOL. 55$]$
A. B. Macallum.

\section{NEW FOREIGN MEMBERS OF THE ROYAL SOCIETY.}

$W^{E}$ are able to give this week portraits of the recently elected foreign members of the Royal Society-Giovanni V. Schiaparelli, the Astronomer and Director of the Royal Brera Observatory in Milan; Prof. Albert Heim, the geologist, Professor of Geology in the Hochschule and Polytechnische Schule of Zürich ; Prof. Gabriel Lippmann, Professor of Physics in the University of Paris, and a Director of the Physics Laboratory of the Sorbonne École des Hautes Études; and Prof. Gösta Mittag-Leffler, Professor of Pure Mathematics in the Hochschule, and Director of the Mathematische Seminar at Stockholm.

Prof. Giovanni V. Schiaparelli is best known for his researches in meteoric and cometary astronomy, and for his acute observation of planetary characteristics. He is the author of numerous papers in the Milan Rendiconti, the Journal de Physique, the Annalen der Physik, in the Comptes rendus, in Les Mondes, and elsewhere. In 1867 his papers, "Intorno al corso ed all' origine probabile delle stelle meteoriche," "Sur la relation qui existe entre les comètes et les étoiles filantes" (Astronomische Nachrichten), and "Sur l'origine des étoiles filantes de Novembre" appeared. Later came "Sul calcolo di Laplace intorno alla probabilità delle orbite cometarie iperboliche," and " Nuovi fatti e nuove teorie sulla repulsione nelle comete"; and more recently "Osservazioni astronomiche e fisiche sull' asse di rotazione e sulla topografia del Pianeta Marte," "Observations de la tache polaire australe de Mars pendant l'opposition de 1879 ," and a number of other papers on this planet. His observations of Mercury and Venus, which led him to conclude that the period of rotation of each of these planets is the same as that of revolution around the sun, are also noteworthy contributions to astronomy.

Prof. Heim is well-known for his work in reference to glacial action and to mountain structure. Among his more important published works are his " Handbuch der Gletscher Kunde," published in I884, and his "Untersuchungen über den Mechanismus der Gebirgsbildung," besides a number of occasional contributions to scientific literature, including various papers on Glaciers, printed in the Annales Phys. Chem., in the Sehweizer. Naturf. Gesellschaft Verhandlungen, \&c., in the Zurich Vierteljahrschrift, \&c., also "Les tremblements de terre et leur étude scientifique," in the Archives Sci. Phys. Nat.

Prof. Lippmann is well known to men of science by his important observations respecting electro-capillary phenomena, leading to his invention of the capillary electrometer; and by his recent researches upon colour photography, in which he has attained the optical solution of a problem at one time considered insoluble. By photographic processes he has produced brilliant pictures, not only of the spectrum and simple coloured subjects, but also of landscapes and figures. Among his other published works are numerous contributions to the Journal de Physique, the Revue Scientifique, the Comptes rendus, $\& c .$, on the relations between electrical and capillary phenomena, on units of electrical force, on experimental determinations of the ohm, and kindred subjects.

Prof. Gösta Mittag-Leffler, whose name is familiar as the founder and editor of the Acta Mathematica, is distinguished for his researches in the theory of functions and in other regions of pure mathematics. His published papers are numerous, and have appeared principally in the Stockholm Ofversigt, in the Acta Societae Scientiarum, Helsingfors, and in the Paris Comptes rendus. Among the more important may be mentioned a series of papers in the Ofversigt, " $\mathrm{Om}$ den analytiska framstellningen af funktioner utaf rationel karakter," "Funktionsteoretiska Studier" in the Helsingfors Acta. "Sur la theorie des fonctions uniformes d'une variable" in the Paris Comptes

rendus, \&c. 